\title{
Theory of boundaryless career and employability training in higher education
}

\author{
Zhiguo Liu, Guanghui Chen \\ Qinhuangdao Institute of Technology, \\ Qinhuangdao China \\ E-mail address: qhdlzg666@sina.com \\ chenguanghui@pku.edu.cn
}

\begin{abstract}
In the present work, we introduced the theory, faced predicament and defects of traditional career, the theory and development of boundaryless career, as well as its enlightenment on employability training in colleges.
\end{abstract}

Keywords-boundaryless career; traditional career; higher education; employability

\section{THEORY OF TRADITIONAL CAREER}

\section{A. Theory of traditional career and the faced predicament}

In the past, the theory of traditional career described one's lifetime career basically accurately, and also became a guiding principle of making career development plan for employees $^{[1]}$.

When the theory of traditional career studies people's professional conduct, it is not enough on the development law of career itself, such as social division of labor, industry division, career structure mobility, etc. At present, however, the boundary of the old framework has been broken through. Flow inside organization becomes movement inside or between organizations, and relatively disciplinary career plan path gradually becomes relatively uncertain plan path. In addition, because individual career role itself is influenced by organization restructuring, technical renovation, etc., it is being endowed with new meaning, which is also a change ${ }^{[2]}$. In this day and age, the theory of traditional career has fallen into dire straits.

$B$. Defects of traditional career

1) Traditional career neglects individual development outside organization

Organizing individual career development only considers inside an organization, vertical promotion or level adjustment, while seldom thinks of individual development outside organization. With the change of organization structure, however, many employees are hard to realize their career development plan inside organization.

2) Traditional career neglects development trend of individual career

In the increasingly fierce competitive environment, manager's control ability on the future development trend of organization becomes lower and lower. Needs to adjust constantly management direction, selects different technicians and managers, eliminates less competent, low efficient employees. For the laid-off employees, there is no management of organization to their career.

\section{THEORY OF BOUNDARYLESS CAREER AND DEVELOPMENT}

\section{A. Theory of boundaryless career}

The concept of boundaryless career first appeared in 1990s presented by Arthur in the special issue of Journal of Organizational Behavior in 1994. It refers to "a series of employment opportunities beyond the boundary of single employment environment" ${ }^{\text {[3] }}$. Different with traditional career, boundaryless career highlights employability improvement in place of long-term employment assurance, enabling employees to realize sustained employment across different organizations.

The "boundary" in "boundaryless career" can be interpreted as career boundary, organization boundary, employment relationship boundary, work role boundary, etc. Boundaryless career is not also used to describe a development trend of modern career, but also to represent a mode of individual career development. As a development trend of career, boundaryless career breaks through the hypothesis that organization can provide employment for life, and highlights the instability and turbulence of modern career ${ }^{[4]}$.

Using the concept of boundaryless career, Arthur describes the fact that the career of many people is no longer "bound" or "regulated" by organization. In 1996, Arthur and Rousseau further revise and enrich the theory of boundaryless career, and it develops into an influential concept gradually. This means that besides individual transfer inside and outside organization, the accumulation of transfer ability and personal identity are also important factor of judging boundaryless career. Under the mode of boundaryless career, employees will be beyond a series of job opportunities set by a certain or single employment scope, e.g., employees will no longer finish lifetime career in one or two organizations, but realize their career in more organizations, more occupations and more posts.

B. Background of boundaryless career

1) Career changes rapidly due to industrial restructuring and technical upgrading

With the constant increase of new occupation style, old occupation style is dying out. Taking America as an example, in recent 5 years, 7000 occupations disappeared while 8000 new occupations were added. This means that skills and experiences learned in the past are not enough to satisfy current and future need of a job. When some old jobs disappear or some new jobs appear, employees' employability 
appears to be very critical, especially for their core employability.

\section{2) Influence of organization transformation}

Since the later 19 th century, the rival environment that enterprises confront changes rapidly. Especially with the rapid development of information technology and knowledge economy since 1990s, organization has been changing fundamentally. It develops from traditional bureaucracy to more flexible and more flat organizational form, and diverse development trend appears, such as informationization, decentralization, virtualization, miniaturization, etc.

3) Influence of the rise of services

Since the later 19 th century, the rival environment that enterprises confronted changed rapidly. Especially with the rapid development of information technology and knowledge economy since 1990s, organization has been changing fundamentally. It develops from traditional bureaucracy to more flexible and more flat organizational form, and diverse development trend appears, such as informationization, decentralization, virtualization, miniaturization, etc.

\section{ENLIGHTENMENT OF BOUNDARYLESS CA- REER ON EMPLOYABILITY TRAINING IN HIGHER EDUCATION}

\section{A. enlightenment Traditional career has changed to bound-} aryless career

Individual faces more tough competition and more frequent job change; Individual no longer finishes lifetime career in one or two organizations, but realizes his career in more organizations, more occupations and more posts; Variable and unstable employment environment requires that colleges need to improve employability of students during talents training. This, on the one hand, sets up obstacles for individual career development, and also provides direction for the cultivation and development of individual employability of students. Colleges must be soberly aware that boundaryless career will have great influence on their talents training mode ${ }^{[5]}$. Under the mode of boundaryless career, college graduates are no longer possible to plan their career based on a lengthy period, and it is also very difficult to position their job and life opportunity in the stability of organization.

Cultivating and improving the employability of college students become one of key factors of successful talents training in colleges under the mode boundaryless career.

$B$. Boundaryless career is a career development trend

Boundaryless career is a development trend of career in knowledge economy era, and also is a main development trend of career that higher vocational college students are facing and will face inside next long time. Under the mode of boundaryless career, employability not only affects their original employment, but also affects their employment transition, and more affects the sustainable development of their career.
Come nearly 10 years, Chinese higher education developed rapidly. Since the rapid expansion of colleges, in a short period of over ten years, the scale of higher education has been expanded. However, the quality development of our higher education still is in the primary stage. Many colleges are still very short-sighted and utilitarian on school-running concept and talents training mode. Most of colleges pay much attention to the transmission of knowledge, but despise the cultivation of employability, especially neglect the cultivation of core employability, neglect the cultivation of professionalism and values, simplify "job-oriented" as "employment rate" of pursuing single numbers game ${ }^{[6]}$.

\section{Boundaryless career highlights employability}

Under the background of traditional career, individual professional skills are a deciding factor for individual to be adequate to his job. Professional competence often is a key factor of individual promotion and reuse. Under the mode of boundaryless career, however, employability becomes a deciding factor for individual success.

Cultivating talents is not "making machine". As colleges cultivate professional knowledge and professional skills of students, they should pay much attention to the cultivation of employability, especially for core employability, resulting in the sustained employment of students across different organizations. This is more accord with the idea of boundaryless career. Must center on improving employability, innovate system mechanism of talents training, deepen the innovation of talents training mode, especially make whole reform and innovate on teaching content, teaching method, teaching technology, teaching environment, teaching value, etc.

\section{REFERENCES}

[1] BURTON J BLEDSTEIN. The Culture of Professionalism: The Middles Class and the Development of Higher Education in America, New York: W. W. Norton, 1978, PP. 171-172.

[2] Arthur, M.B. The Boundaryless career: A new perspective for organizational inquiry. Journal of organizational Behavior, vol. 15, pp. 295306, 1994.

[3] Sullivan, Sherry E. The changing nature of careers: a review and research agenda, Journal of Management, vol.25, pp. 457-484, 1999.

[4] Joseph C, et al. State Performance Reporting Indications:What Do They Indicate? Planning for Higner Education. Vol. 31, pp. 15-29, 2002.

[5] PHILIP BROWN, RICHARD SCASE. Higher Education and Corporate Realities, London: UCL.1994.20.

[6] Gazier, B. (1999). Employability: concepts and policies. Berlin: European Commission, Employment and Social Affairs. 